\title{
Sinomonas mesophila sp. nov., isolated from ancient fort soil
}

\author{
Deene Manik Prabhu ${ }^{1,2,7}$, Syed Raziuddin Quadri ${ }^{3,7}$, Juan Cheng ${ }^{4}$, Lan Liu', Wei Chen ${ }^{5}$, Ying Yang ${ }^{5}$, \\ Wael N Hozzein ${ }^{6}$, Kattimani Lingappa ${ }^{2}$ and Wen-Jun $\mathrm{Li}^{1,4}$
}

A moderate growing strain designated as MPKL $26^{\top}$ was isolated from a soil sample of Bidar Fort, Karnataka, India. The strain MPKL $26^{\top}$ was Gram positive, bent rod in shape. The optimum pH and temperature for growth was 7.0 and $30^{\circ} \mathrm{C}$, respectively. The $16 \mathrm{~S}$ ribosomal RNA gene sequence analysis revealed that strain MPKL $26^{\top}$ was closely related to $S$. atrocyanea DSM $20127^{\top}(98.09 \%)$, S. flava CW $108^{\top}(98.04 \%)$, S. soli CW $59^{\top}(97.99 \%)$ and S. notoginsengisoli SYP-B575 ${ }^{\top}(97.0 \%)$ and showed DNA-DNA hybridization relatedness $(46.05 \pm 1.2,33.56 \pm 2.55,32.56 \pm 1.7$ and $26.79 \pm 2.5$, respectively, between these strains) less than the threshold value for the delineation of genomic species. The peptidoglycon type was A3 $\alpha$ type with glycine, alanine, lysine and glutamic acid as the amino acids. The whole-cell sugars were fructose, ribose, mannose, glucose and galactose. The polar lipids were diphosphatidylglycerol, phosphatidylglycerol and phosphatidylinositol along with three unknown polar lipids. The fatty acid profile contained $C_{14: 0}, C_{16: 0}$, iso- $C_{14: 0}$, iso- $C_{15: 0}$, iso- $C_{16: 0}$, iso- $C_{17: 0}$, anteiso- $C_{15: 0}$, anteiso- $C_{17: 0}$ and summed feature $4(17: 1$ iso I/anteiso $B)$. The predominant respiratory quinine was $M K-9\left(\mathrm{H}_{2}\right)$ with $\mathrm{MK}-10\left(\mathrm{H}_{2}\right)$, MK-8 $\left(\mathrm{H}_{2}\right)$ and MK-8 $\left(\mathrm{H}_{4}\right)$ as minor respiratory quinines. The $\mathrm{G}+\mathrm{C}$ content of the genomic DNA was $68.8 \mathrm{~mol} \%$. On the basis of phenotypic, chemotaxonomic and molecular characteristics, the strain MPKL $26^{\top}$ represents a novel species of the genus Sinomonas, for which the name Sinomonas mesophila sp. nov. is proposed with MPKL $26^{\top}$ as the type strain $\left(=\mathrm{NCIM} 5552^{\top}=\mathrm{JCM} 30094^{\top}\right)$. The Journal of Antibiotics (2015) 68, 318-321; doi:10.1038/ja.2014.161; published online 3 December 2014

\section{INTRODUCTION}

The genus Sinomonas was first proposed by Zhou et al. ${ }^{1}$ with the newly isolated strain S. flava CW $108^{\mathrm{T}}$ (the type species of the genus) and S. atrocyanea DSM $20127^{\mathrm{T}}$ (previously classified as Arthrobacter atrocyaneus). Soon after the genus published, another two species Arthrobacter echigonensis and Arthrobacter albidus were reclassified to the genus Sinomonas as $S$. echigonense and S. albida. ${ }^{2}$ At the time writing, one more species of this genus, S. notoginsengisoli was proposed by Zhang et al. ${ }^{3}$ The characteristic features of this genus are: the cells are bent rod in shape and has a high $\mathrm{G}+\mathrm{C}$ content $(66.6-71.8 \mathrm{~mol} \%){ }^{1-4}$ During the investigation on the biodiversity of microorganisms from soils of Bidar Fort (Karnataka, India), one strain designated as MPLK $26^{\mathrm{T}}$ was isolated; the $16 \mathrm{~S}$ ribosomal RNA (rRNA) gene sequence analysis revealed that strain MPKL $26^{\mathrm{T}}$ was closely related to S. atrocyanea DSM $20127^{\mathrm{T}}(98.09 \%)$, S. flava CW $108^{\mathrm{T}}$ (98.04\%), Si. soli CW 59 $9^{\mathrm{T}}(97.99 \%)$ and S. notoginsengisoli SYP-B575 (97.0\%). The low $16 \mathrm{~S}$ rRNA gene sequence relatedness $(<98.5 \%)$ encouraged us to carry out the phenotypic, chemotaxonomic and molecular characterization in order to classify the taxonomic position of the strain MPLK $26^{\mathrm{T}}$. On the basis of these results, it was found that the strain MPKL $26^{\mathrm{T}}$ represents a novel species of the genus Sinomonas, for which the name S. mesophila sp. nov. is proposed.

\section{MATERIALS AND METHODS}

Strain and culture conditions

Strain MPKL $26^{\mathrm{T}}$ was isolated from the soil sample collected from Bidar Fort $\left(17^{\circ} 55^{\prime} 19^{\prime \prime} \mathrm{N} 77^{\circ} 31^{\prime} 24^{\prime \prime} \mathrm{E}\right)$, Karnataka, India, by serial dilution plating method using International Streptomyces project (ISP) 4 medium. ${ }^{5}$ The purified strain was maintained on yeast extract-malt extract agar (ISP 2 medium) ${ }^{5}$ slants at $4{ }^{\circ} \mathrm{C}$ for short-term preservation and as glycerol suspensions $(20 \%, \mathrm{v} / \mathrm{v})$ at $-80^{\circ} \mathrm{C}$ for long-term preservation. The reference strains S. atrocyanea DSM $20127^{\mathrm{T}}$, S. flava CW $108^{\mathrm{T}}$, S. soli CW $59^{\mathrm{T}}$ and S. notoginsengisoli SYP-B $575^{\mathrm{T}}$ were selected for the comparison of phenotypic characterization, DNA-DNA relatedness evaluation and chemotaxonomic determination.

${ }^{1}$ State Key Laboratory of Biocontrol, Key Laboratory of Biodiversity Dynamics and Conservation of Guangdong Higher Education Institutes, College of Ecology and Evolution, Sun Yat-Sen University, Guangzhou, China; ${ }^{2}$ Department of Microbiology, Gulbarga University, Gulbarga, India; ${ }^{3}$ Department of Medical Laboratory Technology, Faculty of Applied Medical Sciences, Northern Border University, Arar, Kingdom of Saudi Arabia; ${ }^{4}$ Key Laboratory of Microbial Diversity in Southwest China, Ministry of Education, Yunnan Institute of Microbiology, Yunnan University, Kunming, China; ${ }^{5}$ China Tobacco Yunnan Industrial Co., Ltd, Kunming, China and ${ }^{6}$ Department of Zoology, Bioproducts Research Chair (BRC), College of Science, King Saud University, Riyadh, Kingdom of Saudi Arabia

${ }^{7}$ These authors contributed equally to this work.

Correspondence: Professor K Lingappa, Department of Microbiology, Gulbarga University, Gulbarga, Karnataka, India.

E-mail: lingappak1@rediffmail.com

or Professor W-J Li, State Key Laboratory of Biocontrol, Key Laboratory of Biodiversity Dynamics and Conservation of Guangdong Higher Education Institutes, College of Ecology and Evolution, Sun Yat-Sen University, No.135, Xinggang West Road, Guangzhou 510275, China.

Email: liwenjun3@mail.sysu.edu.cn

Received 29 July 2014; revised 12 October 2014; accepted 1 November 2014; published online 3 December 2014 


\section{Phenotypic characteristics}

The morphological, physiological and biochemical characters were observed on YDC and TYB or PYES agar media at $30^{\circ} \mathrm{C}$ unless mentioned. ${ }^{6,7}$ Gram staining was carried out by using the standard Gram reaction. The morphological properties of strain MPKL $26^{\mathrm{T}}$ were observed with the aid of light microscopy (BH-2; Olympus optical co. Ltd., Tokyo, Japan) and scanning electron microscopy (QUANTA 200; FEI company, Hillsboro, OR, USA). For scanning electron microscopy, cultured cells were harvested by centrifugation, washed and suspended in $20 \mathrm{~mm}$ phosphate buffer ( $\mathrm{pH}$ 7.0). The suspended cells were fixed with $2.5 \%$ glutaraldehyde. The cells were dehydrated in an ethanol series $(\mathrm{v} / \mathrm{v})$ ranging from $30,60,90$ and $100 \%$. Cells were dried to a critical drying point. Further, samples were coated with gold and observed under a scanning electron microscope. Growth at various temperature range $(5,10,15,20,25$, $30,35,40,45,50,55$ and $60^{\circ} \mathrm{C}$ ) and $\mathrm{pH}$ range $4.0-10.0$ (at intervals of $1.0 \mathrm{pH}$ unit) was performed using the buffer system as described by Xu et al. ${ }^{8}$ The sodium chloride tolerance at various concentrations $(0,0.5,1,1.5,2,3$ and $5.0 \% \mathrm{w} / \mathrm{v})$ was observed. Catalase activity was determined based on the production of bubbles after the addition of a drop of $3 \%(\mathrm{v} / \mathrm{v}) \mathrm{H}_{2} \mathrm{O}_{2}$. Oxidase activity was determined based on oxidation of tetramethyl p-phenylenediamine. ${ }^{9}$ Cellulose, gelatin, starch; Tweens $(20,40,60$ and 80$)$ hydrolysis; milk coagulation and peptonization were performed as described by Gonzalez et al. ${ }^{10}$ and other biochemical test was performed by standard methods. ${ }^{11}$ The enzymatic activities were determined by the API ZYM stripe (bioMérieux, France) according to the manufacturer's instruction. Utilization of various substrates as sole carbon sources and chemical sensitivity assays was determined by Biolog GN III (Biolog Inc., Hayward, CA, USA) microplates according to the manufacturer's instruction.

\section{Chemotaxonomy}

The isomer of amino acids in purified cell wall and whole-cell sugar hydrolysates were determined according to the procedures described by Hasegawa et al., ${ }^{12}$ Lechevalier and Lechevalier ${ }^{13}$ and Tang et al. (a, b). ${ }^{14,15}$ Polar lipids were extracted as described by Minnikin et al. ${ }^{8}$ and identified by two-dimensional TLC. ${ }^{17}$ Menaquinones were extracted and analyzed using HPLC. ${ }^{18,19}$ Cellular fatty acid analysis was performed by using the Microbial Identification System (Sherlock Version 6.1; MIDI database: TSBA6; Sasser 1990). Biomass for fatty acid analysis was obtained from cell grown on tryptose soy agar (Difco, Sparks, MD, USA) at $30^{\circ} \mathrm{C}$ for 4 days.

\section{Molecular analysis}

Extraction of genomic DNA and PCR amplification of the 16S rRNA gene of the strain MPKL $26^{\mathrm{T}}$ was performed by our earlier standard protocol..$^{20}$ The

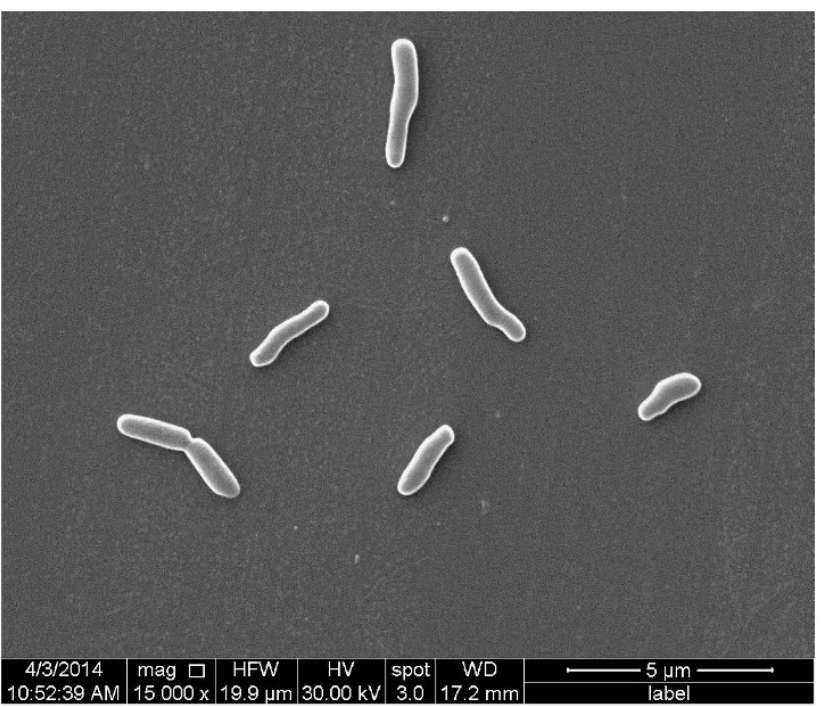

Figure 1 Scanning electron microscope image of strain MPKL $26^{\top}$ after growth on ISP 2 medium at $30^{\circ} \mathrm{C}$ for 2 days. sequence obtained was compared with available 16S rRNA gene sequences of cultured species from the EzTaxon-e server (http://eztaxon-e.ezbiocloud.net/). ${ }^{21}$ Phylogenetic analysis was performed using the software package MEGA version $5.0^{22}$ after multiple alignment of the sequences using CLUSTAL_X program. ${ }^{23}$ Distances (using distance options according to Kimura's two-parameter model; Kimura ${ }^{24}$ were calculated and clustering was performed with the neighborjoining method. ${ }^{25}$ To determine the support of each clade, bootstrap analysis was performed with 1000 replications. ${ }^{26}$ The validity of the neighbor-joining tree was evaluated with maximum-likelihood tree using MEGA 5.0. (Arizona State University, Phoenix, AZ, USA). ${ }^{27,28}$ The G+C content of the genomic DNA was determined by using reversed phase HPLC using Escherichia coli DH5 $\alpha$ as the reference strain. ${ }^{29}$ The DNA-DNA hybridizations with MPKL $26^{\mathrm{T}}$ and its four reference strains (S. atrocyanea DSM $20127^{\mathrm{T}}$, S. flava CW $108^{\mathrm{T}}$, S. soli CW $59^{\mathrm{T}}$ and $S$. notoginsengisoli SYP-B575 ${ }^{\mathrm{T}}$ ) were carried out by using optical renaturation methods, using eight replications for each hybridization reaction. ${ }^{30}$

\section{RESULTS AND DISCUSSION}

\section{Phenotypic characteristics}

Strain MPKL $26^{\mathrm{T}}$ was found to be Gram positive, aerobic and nonmotile. The scanning electron microscope image (Figure 1) revealed that the cells were bent rod in shape, which is the peculiar character of the genus Sinomonas. ${ }^{1}$ Temperature for growth ranged from 20 to $40^{\circ} \mathrm{C}$ with the optimum growth at $30^{\circ} \mathrm{C}$. The $\mathrm{pH}$ for growth ranged from 6 to 8 with the optimum at $\mathrm{pH} 7$. The tolerance to sodium chloride was found to be up to $4 \%(\mathrm{w} / \mathrm{v})$. The strain MPKL $26^{\mathrm{T}}$ grew well on YDC, PYES or TYB with no dark blue color on YDC media, this characteristic feature differentiates it from the strain $S$. atrocyanea DSM $20127^{\mathrm{T}}$. Catalase and Voges-Proskauer test were positive, but oxidase, $\mathrm{H}_{2} \mathrm{~S}$ and indole were negative. Milk coagulation was positive, whereas milk peptonization was negative. The strain hydrolyzed Tween 40 weakly, but not for the other Tweens (20,60 and 80); this feature differentiated the strain from the other reference type strains (DSM $20127^{\mathrm{T}}, \mathrm{CW}^{2} 9^{\mathrm{T}}$ and $\left.\mathrm{CW} 108^{\mathrm{T}}\right)$. The strain MPKL $26^{\mathrm{T}}$ could utilize dextrin, D-trehalose, D-fructose, 3-methyl glucose, D-glucose-6- $\mathrm{PO}_{4}$, D-fructose-6- $\mathrm{PO}_{4}$, D-aspartic acid, L-aspartic acid, L-glutamic acid, L-histidine, D-galacturonic acid, D-glucuronic acid, $\alpha$-keto-glutaric acid, D-malic acid and L-malic acid, whereas pectin and methyl pyruvate were weakly utilized; these sources of utilization found consistence in reference type strains (DSM $20127^{\mathrm{T}}, \mathrm{CW} 59^{\mathrm{T}}$ and CW $108^{\mathrm{T}}$ ). In contrast to the above, D-fucose was only utilized by the strain MPKL $26^{\mathrm{T}}$. In addition to the above, the production of valine arylamidase and sensitivity to fusidic acid and vancomycin were differential characteristic of the strain MPKL $26^{\mathrm{T}}$. A details characteristic features of the strain MPKL $26^{\mathrm{T}}$ and its type strains were mentioned in Tables 1 and 2.

\section{Chemotaxonomic characteristics}

The peptidoglycon type was A3 $\alpha$ type with glycine, alanine, lysine and glutamic acid as the amino acids. The strain MPKL $26^{\mathrm{T}}$ contains fructose, ribose, mannose, glucose and galactose as whole-cell sugars; in comparison with the strain MPKL $26^{\mathrm{T}}$, the whole-cell sugar, fructose was devoid in the other type strains ( $S$. atrocyanea DSM $20127^{\mathrm{T}}$, S. flava CW $108^{\mathrm{T}}$, S. soli CW $59^{\mathrm{T}}$ and S. notoginsengisoli SYP$\left.\mathrm{B} 575^{\mathrm{T}}\right)$. The polar lipids were diphosphatidylglycerol, phosphatidylglycerol and phosphatidylinositol along with three unknown polar lipids (Supplementary Figure S1). The cellular fatty acid compositions (\%) of strain MPKL $26^{\mathrm{T}}$ and its reference type strains were mentioned in Table 3. The predominant respiratory quinine was MK-9( $\left.\mathrm{H}_{2}\right)$ with MK-10 $\left(\mathrm{H}_{2}\right)$, MK-8 $\left(\mathrm{H}_{2}\right)$ and MK- $8\left(\mathrm{H}_{4}\right)$ as minor respiratory quinines.

\section{Phylogenetic analysis and DNA-DNA relatedness}

An almost complete 16S rRNA gene sequence (1528 bp) was obtained. The blast result indicated that the strain MPKL $26^{\mathrm{T}}$ showed high 
Table 1 Morphological and physiological characteristics of strain MPKL $26^{\top}$ and the related type strains of the genus Sinomonas

\begin{tabular}{|c|c|c|c|c|c|}
\hline Characteristic & 1 & 2 & 3 & 4 & 5 \\
\hline \multicolumn{6}{|l|}{ Colony color on } \\
\hline YDC agar & CW & DB & PY & CW & PY \\
\hline TYB or PYES agar & $\mathrm{CW}$ & GW & PY & PY & PY \\
\hline Citric acid & W & - & + & W & W \\
\hline Catalase & + & + & W & + & + \\
\hline Tween 80 & - & - & W & + & - \\
\hline \multicolumn{6}{|l|}{ API ZYM } \\
\hline Esterase (C-4) & + & W & + & + & + \\
\hline Esterase lipase (C-8) & + & W & + & + & + \\
\hline Leucine arylamidase & + & + & + & W & + \\
\hline Valine arylamidase & + & - & - & - & + \\
\hline Phosphohydrolase & + & + & W & + & + \\
\hline$\beta$-Galactosidase & - & - & W & W & - \\
\hline$\beta$-Glucuronidase & - & - & + & + & + \\
\hline$\alpha$-Glucosidase & + & W & + & + & + \\
\hline$\beta$-Glucosidase & + & - & + & + & + \\
\hline$\alpha$-Mannosidase & - & - & W & W & - \\
\hline \multicolumn{6}{|l|}{ Utilization of } \\
\hline Glycerol & + & - & + & - & + \\
\hline D-glucose & + & + & + & - & + \\
\hline Sorbitol & + & - & W & - & + \\
\hline $\mathrm{N}$-acetylglucosamine & W & - & - & + & W \\
\hline Salicin & + & - & W & - & W \\
\hline Cellobiose & W & - & W & - & W \\
\hline Maltose & W & - & W & - & + \\
\hline Sucrose & W & + & W & + & + \\
\hline Turanose & + & w & W & + & + \\
\hline D-maltose & W & W & W & W & + \\
\hline
\end{tabular}

Abbreviations: CW, creamy white; DB, dark blue; GW, gray white; PY, pale yellow. Strains: (1) MPKL $26^{\top}$; (2) S. atrocyanea DSM $20127^{\top}$; (3) S. flava CW $108^{\top}$; (4) S. soli CW. $59^{\top}$; (5) S. notoginsengisoli SYP-B $575^{\top} .+$, positive; - , negative; W, weakly positive.

Table 2 Chemical and antibiotic susceptibility of strain MPKL $26^{\top}$ and the related type strains of the genus Sinomonas

\begin{tabular}{llllll}
\hline Chemicals/antibiotics & T & 2 & 3 & 4 & 5 \\
\hline Fusidic acid & S & W & W & W & W \\
Guanidine hydrochloride & S & S & S & S & S \\
Lithium chloride & S & W & S & S & S \\
Sodium butyrate & R & R & R & R & R \\
Sodium bromated & W & W & W & S & W \\
Tetrazolium violet & W & R & W & W & W \\
Tetrazolium blue & S & R & S & S & S \\
Nalidixic acid & R & R & R & R & R \\
Niaproof 4 & S & S & S & S & S \\
Troleandomycin & W & W & W & W & W \\
Lincomycin & W & R & W & W & W \\
Minocycline & W & W & W & W & W \\
Rifamycin & S & W & W & W & W \\
Vancomycin & S & W & W & W & W \\
\hline
\end{tabular}

Strains: (1) MPKL 26 $6^{\top}$; (2) S. atrocyanea DSM $20127^{\top}$; (3) S. flava CW $108^{\top}$; (4) S. soli CW $59^{\top}$; (5) S. notoginsengisoli SYP-B575 ${ }^{\top}$. S, sensitive; R, resistant; W, weakly positive.

similarities to S. atrocyanea DSM $20127^{\mathrm{T}}$ (98.09\%), S. flava CW $108^{\mathrm{T}}$ (98.04\%), S. soli CW 59 ${ }^{\mathrm{T}}(97.99 \%)$ and S. notoginsengisoli SYP-B575 ${ }^{\mathrm{T}}$ (97.0\%). The obtained sequence was submitted to GenBank under the accession number (KJ809567). The neighbor-joining tree (Figure 2)
Table 3 Cellular fatty acid compositions (\%) of strain MPKL $26^{\top}$ and its reference type strains: (1) MPKL $26^{\top}$, (2) S. atrocyanea DSM $20127^{\top}$, (3) S. flava CW $108^{\top}$, (4) S. soli CW $59^{\top}$ and (5) S. notoginsengisoli SYP-B575

\begin{tabular}{|c|c|c|c|c|c|}
\hline Fatty acids & 1 & 2 & 3 & 4 & 5 \\
\hline $\mathrm{C}_{12: 0}$ & - & - & 1.1 & - & - \\
\hline $\mathrm{C}_{14: 0}$ & 0.6 & - & 0.7 & 0.5 & - \\
\hline $\mathrm{C}_{12: 0} 3 \mathrm{OH}$ & - & - & 0.5 & - & - \\
\hline$C_{16: 0}$ & 2.0 & 1.2 & 2.6 & 2.2 & 1.1 \\
\hline$C_{18: 1} w 9 c$ & - & - & 0.9 & - & - \\
\hline Iso- $C_{13: 0}$ & - & - & 0.5 & - & - \\
\hline Iso- $\mathrm{C}_{14: 0}$ & 0.8 & 1.6 & 0.6 & 2.3 & - \\
\hline Iso- $\mathrm{C}_{15: 0}$ & 31.3 & 21.8 & 29.0 & 14.1 & 23.6 \\
\hline Iso- $\mathrm{C}_{16: 0}$ & 4.2 & 4.8 & 1.5 & 11.2 & 1.3 \\
\hline Iso- $\mathrm{C}_{17: 0}$ & 5.1 & 1.1 & 1.3 & 1.4 & 2.7 \\
\hline Anteiso- $C_{15: 0}$ & 35.9 & 57.0 & 43.1 & 51.3 & 53.9 \\
\hline Anteiso- $C_{17: 0}$ & 15.4 & 8.5 & 6.0 & 11.6 & 11.2 \\
\hline Summed feature 3 ( $16: 1$ w7c/16:1 w6c) & - & - & 4.4 & - & - \\
\hline Summed feature 4 (17:1 iso I/anteiso $B)$ & 3.9 & 2.5 & 6.1 & 4.1 & 4.3 \\
\hline
\end{tabular}

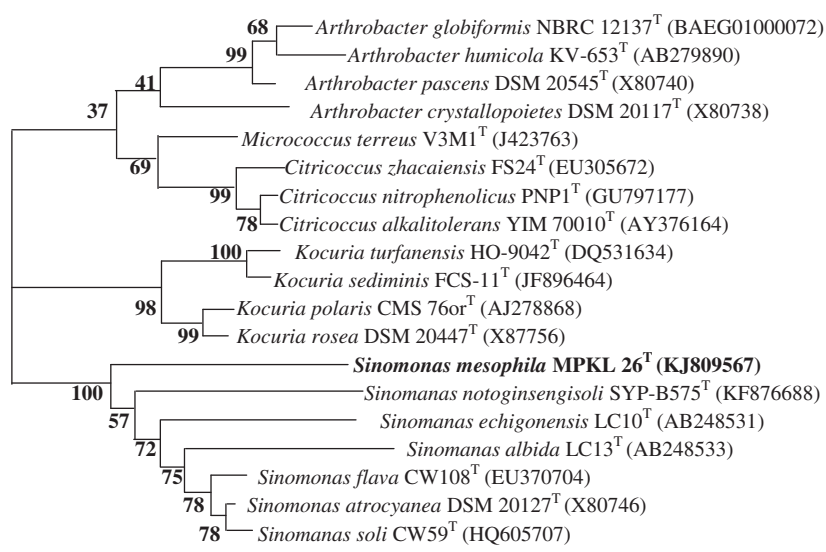

0.005

Figure 2 Neighbor-joining phylogenetic tree based on 16S ribosomal RNA gene sequence, showing the position of strain MPKL $26^{\top}$. Bootstrap values were shown as percentages of 1000 replicates.

showed that the strain MPKL $26^{\mathrm{T}}$ clustered closely with the members of the genus Sinomonas. The cluster further found stable when the tree constructed by using maximum-likelihood method (Supplementary Figure S2). On the basis of phylogenetic analysis, the new isolate MPKL $26^{\mathrm{T}}$ should be affiliated to the genus Sinomonas.

The $\mathrm{G}+\mathrm{C}$ content of strain MPKL $26^{\mathrm{T}}$ was determined to be $68.8 \mathrm{~mol} \%$, which was within the range of the members of the genus Sinomonas $(66.6-71.8 \mathrm{~mol} \%) .^{1-4}$ DNA-DNA hybridization values between strain MPKL $26^{\mathrm{T}}$ and its closest phylogenetic neighbors, S. atrocyanea DSM $20127^{\mathrm{T}}$, S. flava CW $108^{\mathrm{T}}$, S. soli CW $59^{\mathrm{T}}$ and S. notoginsengisoli SYP-B575 ${ }^{\mathrm{T}}$ were $46.05 \pm 1.2,33.56 \pm 2.55,32.56 \pm 1.7$, $26.79 \pm 2.5$, respectively. The DNA-DNA hybridization values were less than the cutoff point $(70 \%)$, which was considered to be the threshold value for the delineation of genomic species. ${ }^{31}$ On the basis of morphological, biochemical and molecular characters, the strain MPKL $26^{\mathrm{T}}$ represents a novel species of the genus Sinomonas, for which we propose the name $S$. mesophila sp. nov. 


\section{Description of $S$. mesophila sp. nov.}

S. mesophila (me.so'phi.la. N.L. fem. adj. mesophila; refers to temperature-loving character)

Cells are Gram positive, non-motile, bent rods and aerobic in nature. Colonies are creamy white, circular and convex after $24 \mathrm{~h}$ cultivation at $30^{\circ} \mathrm{C}$ on TYB, YDC or PYES agar, respectively. Mesophilic type of growth occurs with a temperature range $\left(20-40^{\circ}\right.$ C) and $\mathrm{pH}$ range (6-8) with the optimum growth at $30^{\circ} \mathrm{C}$ and $\mathrm{pH} 7$. Growth occurs up to $4 \%$ (w/v) sodium chloride. Catalase and VogesProskauer test are positive, but oxidase, $\mathrm{H}_{2} \mathrm{~S}$ and indole are negative. Milk coagulation is positive, whereas milk peptonization is negative. Tween 40 is weakly hydrolyzed, whereas starch, cellulose, gelatin and Tweens (20, 60 and 80) are not. Dextrin, D-trehalose, D-turanose, D-raffinose, D-melibiose, D-salicin, $\alpha$-D-glucose, D-fructose, D-galactose, 3-methyl glucose, L-rhamnose, D-sorbitol, D-mannitol, glycerol, D-glucose-6 $\mathrm{PO}_{4}, \mathrm{D}$-fructose-6- $\mathrm{PO}_{4}, \mathrm{D}$-aspartic acid, glycyl-L-proline, L-alanine, L-arginine, L-aspartic acid, L-glutamic acid, L-histidine, L-pyroglutamic acid, L-serine, D-galacturonic acid, L-galactonic acid lactone, D-gluconic acid, D-glucuronic acid, mucic acid, quinic acid, D-saccharic acid, D-lactic acid methyl ester, $\alpha$-keto-glutaric acid, D-malic acid, L-malic acid, $\gamma$-amino-butryric acid $\beta$-hydroxy-D, L-butyric acid, acetoacetic acid, propionic acid and acetic acid are utilized, whereas N-acetyl neuraminic acid and bromo-succinic acid are not utilized. Activity for esterase (C-4), esterase lipase (C-8), leucine arylamidase, valine arylamidase, acid phosphatase, phosphohydrolase, $\alpha$-glucosidase and $\beta$-glucosidase are positive. Sensitive to guanidine hydrochloride, fusidic acid, lithium chloride, tetrazolium blue and vancomycin. The peptidoglycan type is A3 $\alpha$ with glycine, alanine, lysine and glutamic acid as the amino acids. The whole-cell sugars are fructose, ribose, mannose, glucose and galactose. The polar lipids are diphosphatidylglycerol, phosphatidylglycerol and phosphatidylinositol along with three unknown polar lipids. The fatty acid profile contains $\mathrm{C}_{14: 0}, \mathrm{C}_{16: 0}$, iso- $\mathrm{C}_{14: 0}$, iso- $\mathrm{C}_{15: 0}$, iso- $\mathrm{C}_{16: 0}$, iso- $\mathrm{C}_{17: 0}$, anteiso- $\mathrm{C}_{15: 0}$, anteiso- $\mathrm{C}_{17: 0}$ and Summed feature 4 (17:1 iso I/anteiso B). The predominant respiratory quinine is $\mathrm{MK}-9\left(\mathrm{H}_{2}\right)$ with $\mathrm{MK}-10$ $\left(\mathrm{H}_{2}\right)$, MK-8 $\left(\mathrm{H}_{2}\right)$ and $\mathrm{MK}-8\left(\mathrm{H}_{4}\right)$ as a minor respiratory quinine. The $\mathrm{G}+\mathrm{C}$ content of strain MPKL $26^{\mathrm{T}}$ is $68.8 \mathrm{~mol} \%$.

The type strain is MPKL $26^{\mathrm{T}}\left(=\mathrm{NCIM} 5552^{\mathrm{T}}=\mathrm{JCM} 30094^{\mathrm{T}}\right)$, which was isolated from the soil of Bidar fort, Karnataka, India.

\section{ACKNOWLEDGEMENTS}

We are grateful to Professor Dr Hans-Peter Klenk (DSMZ, Germany) and Dr Yu Zhou (Institute of Quality and Standard for Agro-products, Zhejiang Academy of Agricultural Sciences, China) for their kind providing the reference type strains, and Dr Syed G Dastager (CSIR-National Chemical Laboratory, Pune) for his help in performing API ZYM experiment. This work was funded jointly by projects of China tobacco Yunnan industrial (Nos. 2012JC07 and 2012FL02). WH and WJL extend their appreciation to the Deanship of Scientific Research at King Saud University for funding this work through the research group no RGP-205. W-J Li was also supported by Guangdong Province Higher Vocational Colleges \& Schools Pearl River Scholar Funded Scheme (2014).

1 Zhou, Y. et al. Proposal of Sinomonas flava gen. nov., sp. nov., and description of Sinomonas atrocyanea comb. nov. to accommodate Arthrobacter atrocyaneus. Int. J. Syst. Evol. Microbiol. 59, 259-263 (2009).
2 Zhou Y. et al. Description of Sinomonas soli sp. nov., reclassification of Arthrobacter echigonensis and Arthrobacter albidus (Ding et al. 2009) as Sinomonas echigonensis comb. nov. and Sinomonas albida comb. nov., respectively, and emended description of the genus Sinomonas. Int. J. Syst. Evol. Microbiol. 62, 764-769 (2012)

3 Zhang, M. Y. et al. Sinomonas notoginsengisoli sp. nov., isolated from the rhizosphere of Panax notoginseng. Antonie van Leeuwenhoek 106, 827-835 (2014).

4 Ding, L., Hirose, T. \& Yokota, A. Four novel Arthrobacter species isolated from filtration substrate. Int. J. Syst. Evol. Microbiol. 59, 856-862 (2009).

5 Shirling, E. B. \& Gottlieb, D. Methods for characterization of Streptomyces species. Int. J. Syst. Bacteriol. 16, 313-340 (1966).

6 Kuhn, D. A. \& Starr, M. P. Arthrobacter atrocyaneus, nov. sp., and its blue pigment. Arch. Microbiol. 36, 175-181 (1960).

7 Wieser, M. et al. Emended descriptions of the genus Micrococcus, Micrococcus luteus (Cohn 1872) and Micrococcus lylae (Kloos et al. 1974). Int. J. Syst. Evol. Microbiol. 52, 629-637 (2002)

$8 \mathrm{Xu}, \mathrm{P}$. et al. Naxibacter alkalitolerans gen. nov., sp. nov., a novel member of the family Oxalobacteraceae isolated from China. Int. J. Syst. Evol. Microbiol. 55 1149-1153 (2005).

9 Kovacs, N. Identification of Pseudomonas pyocyanea by the oxidase reaction. Nature 178, 703-704 (1956).

10 Gonzalez, C., Gutierrez, C. \& Ramirez, C. Halobacterium vallismortis sp. nov., an amylolytic and carbohydrate-metabolizing, extremely halophilic bacterium. Can. J. Microbiol. 24, 710-715 (1978).

11 MacFaddin J. F. in Biochemical tests for identification of medical bacteria, Williams \& Wilkins: Baltimore, MD, USA, (1980).

12 Hasegawa, T., Takizawa, M. \& Tanida, S. A rapid analysis for chemical grouping of aerobic actinomycetes. J. Gen. Microbiol. 29, 319-322 (1983).

13 Lechevalier, M. P. \& Lechevalier, H. A. Chemical composition as a criterion in the classification of aerobic actinomycetes. Int. J. Syst. Bacteriol. 20, 435-443 (1970).

14 Tang, S. K. et al. Zhihengliuella alba sp. nov., and emended description of the genus Zhihengliuella. Int. J. Syst. Evol. Microbiol. 59, 2025-2032 (2009a).

15 Tang, S. K. et al. Kocuria halotolerans sp. nov., an actinobacterium isolated from a saline soil in China. Int. J. Syst. Evol. Microbiol. 59, 1316-1320 (2009b).

16 Minnikin, D. E., Collins, M. D. \& Goodfellow, M. Fatty acid and polar lipid composition in the classification of Cellulomonas, Oerskovia and related taxa. J. Appl. Bacteriol. 47 87-95 (1979).

17 Collins, M. D. \& Jones, D. Lipids in the classification and identification of coryneform bacteria containing peptidoglycan based on 2, 4-diaminobutyric acid. Appl. Bacteriol. 48, 459-470 (1980).

18 Collins, M. D., Pirouz, T., Goodfellow, M. \& Minnikin, D. E. Distribution of menaquinones in actinomycetes and corynebacteria. J. Gen. Microbiol. 100, 221-230 (1977).

19 Kroppenstedt, R. M. Separation of bacterial menaquinones by HPLC using reverse phase (RP18) and a silver loaded ion exchanger as stationary phases. J. Liq. Chromatogr. 5, 2359-2367 (1982).

$20 \mathrm{Li}$, W. J. et al. Georgenia ruanii sp. nov, a novel actinobacterium isolated from forest soil in Yunnan (China) and emended description of the genus Georgenia. Int. J. Syst. Evol. Microbiol. 57, 1424-1428 (2007).

$21 \mathrm{Kim}, \mathrm{O}$. S. et al. Introducing EzTaxon-e: a prokaryotic 16S rRNA gene sequence database with phylotypes that represent uncultured species. Int. J. Syst. Evol. Microbiol. 62, 716-721 (2012).

22 Tamura, K. et al. MEGA5: molecular evolutionary genetics analysis using maximum likelihood, evolutionary distance, and maximum parsimony methods. Mol. Biol. Evol. 28, 2731-2739 (2011)

23 Thompson, J. D. et al. The CLUSTAL $X$ windows interface: flexible strategies for multiple sequence alignment aided by quality analysis tools. Nucleic Acids Res. 25, 4876-4882 (1997).

24 Kimura, M. A simple method for estimating evolutionary rates of base substitutions through comparative studies of nucleotide sequences. J. Mol. Evol. 16, 111-120 (1980).

25 Saitou, N. \& Nei, M. The neighbor-joining method: a new method for reconstructing phylogenetic trees. Mol. Biol. Evol. 4, 406-425 (1987).

26 Felsenstein, J. Confidence limits on phylogenies: an approach using the bootstrap. Evolution 39, 783-79 (1985).

27 Fitch, W. M. Toward defining the course of evolution: minimum change for a specific tree topology. Syst. Zool. 20, 406-416 (1971).

28 Felsenstein, J. Evolutionary trees from DNA sequences: a maximum likelihood approach. J. Mol. Evol. 17, 368-376 (1981).

29 Mesbah, M., Premachandran, U. \& Whitman, W. B. Precise measurement of the $\mathrm{G}+\mathrm{C}$ content of deoxyribonucleic acid by high-performance liquid chromatography. Int. J. Syst. Bacteriol. 39, 159-167 (1989).

30 Ezaki, T., Hashimoto, Y. \& Yabuuchi, E. Fluorometric deoxyribonucleic aciddeoxyribonucleic acid hybridization in microdilution wells as an alternative to membrane filter hybridization in which radioisotopes are used to determine genetic relatedness among bacterial strains. Int. J. Syst. Bacteriol. 39, 224-229 (1989).

31 Wayne, L. G. et al. International committee on systematic bacteriology. Report of the ad hoc committee on reconciliation of approaches to bacterial systematics. Int. J. Syst. Bacteriol. 37, 463-464 (1987). 